\title{
Wojciech Skucha
}

\author{
Uniwersytet Jagielloński
}

\section{Wizerunek Roberta Lewandowskiego w wybranych kampaniach promocyjno-reklamowych w latach 2011-2018 \\ The image of Robert Lewandowski in selected promotional and advertising campaigns from 2011 to 2018}

\begin{abstract}
ABSTRAKT
Robert Lewandowski w ostatnich latach stał się jednym z najlepszych piłkarzy świata. Od wielu lat zawodnik Bayernu

Monachium bierze udział również w spotach i kampaniach reklamowych różnych marek. Celem artykułu jest przedstawienie wizerunku Roberta

Lewandowskiego w kampaniach promocyjno-reklamowych, w których wziął udział między 2011 a 2018 rokiem.

Zostanie pokazana analiza wybranych spotów lub kampanii oraz kanałów komunikacji, jakimi promował produkty reklamowanych przez siebie marek. Przedmiotem analizy przygotowanej w oparciu o sporządzony wcześniej klucz kategoryzacyjny będą reklamy czterech wybranych marek z udziałem kapitana piłkarskiej reprezentacji Polski, które miały miejsce $w$ badanym okresie.
\end{abstract}

SŁOWA KLUCZOWE:

piłkarz, wizerunek, marketing, reklama

\begin{abstract}
Robert Lewandowski has become one of the best football players in the world in recent years. For many years, the Bayern Munich player has also participated in spots and advertising campaigns of different brands. The purpose of this article is to present the image of Robert Lewandowski in promotional and advertising campaigns in which he participated between 2011 and 2018. The analysis of selected spots or advertising campaigns and communication channels, thanks to which Polish football player promoted the products of the brands he advertises, will be presented here. The subject of the analysis, prepared on the basis of the categorization key drawn up earlier, will be advertisements and campaigns of four selected brands featuring the captain of Polish national team, which took place in the analysed period.
\end{abstract}

\section{KEYWORDS:}

football player, image, marketing, advertising

Wykaz skrótów: dz. cyt. (dzieło cytowane), art. cyt. (artykuł cytowany), zob. (zobacz), [b.a.] - brak autora 


\section{WPROWADZENIE}

Robert Lewandowski to sportowiec, który w ostatnich latach stał się piłkarzem światowego formatu. Potwierdzeniem ogromnej klasy zawodnika Bayernu Monachium było m.in. wyróżnienie go w grudniu 2020 roku tytułem Piłkarza Roku FIFA. Lewandowski został pierwszym Polakiem w historii, który otrzymał taką nagrodę ${ }^{1}$. Ponadto $w$ sierpniu tego samego roku triumfował on ze swym klubem w Lidze Mistrzów ${ }^{2}$.

Kapitan naszej reprezentacji jest także bardzo rozpoznawalną postacią, cieszącą się popularnością w mediach społecznościowych. Oficjalne konto polskiego sportowca na Facebooku - @rl9official - zostało zarejestrowane 10 grudnia 2010 roku, a obecnie (stan na dzień 7 listopada 2021 roku) obserwują je ponad 23 miliony użytkowników tej platformy. Konto Lewandowskiego zostało zweryfikowane jako jego autentyczny profil, o czym świadczy charakterystyczna niebieska ikonka, widoczna obok nazwy strony poświęconej jego osobie ${ }^{3}$. Profil sportowca na Instagramie nosi natomiast nazwę_rl9 (są to inicjały imienia i nazwiska piłkarza oraz numer na koszulce, z jakim występuje) i również jest zweryfikowany jako jego oficjalne konto. Napastnik Bayernu Monachium może się na nim poszczycić liczbą przeszło 21,8 miliona obserwujących (stan na dzień 7 listopada 2021 roku $)^{4}$. Tak duża liczba obserwatorów na profilach Lewandowskiego w mediach społecznościowych i osiągane sukcesy sportowe powodują, że jego wizerunek jest bardzo rozpoznawalny. Potwierdzeniem tego jest fakt, iż współpracuje on z wieloma znanymi markami.

${ }^{1}$ M. Kmita, FIFA The Best. Robert Lewandowski Piłkarzem Roku na świecie! Historyczny sukces Polaka, „WP Sportowe Fakty” z 17.12.2020 r., https://sportowefakty.wp.pl/pilka-nozna/915173/fifa-the-best-robert-lewandowski-pilkarzem-roku-na-swiecie-historycznysukces-po (dostęp: $4.11 .2021 \mathrm{r}$.).

${ }^{2}$ M. Kmita, Liga Mistrzów. Robert Lewandowski zgarnął wszystko! Dokonał tego jako pierwszy w historii, „WP Sportowe Fakty” z 23.08.2020 r., https://sportowefakty.wp.pl/pilka-nozna/896554/liga-mistrzow-robert-lewandowski-zgarnal-wszystko-dokonal-tego-jakopierwszy-w-h (dostęp: 4.11.2021 r.).

${ }^{3}$ Oficjalny profil Roberta Lewandowskiego na Facebooku, „Facebook.com”, https://www. facebook.com/rl9official (dostęp: 7.11.2021 r.).

${ }^{4}$ Oficjalny profil Roberta Lewandowskiego na Instagramie, „Instagram.com”, https:// www.instagram.com/_rl9/ (dostęp: 7.11.2021 r.). 
Warto podkreślić, że związki sportu z marketingiem nie mają długiej historii. Według definicji, jaką można znaleźć w książce Philipa Kotlera i jego współpracowników, marketing to „proces społeczny i zarządczy, dzięki któremu jednostki i grupy uzyskują to, czego potrzebują i pragną, przez tworzenie oraz wzajemną wymianę produktów i wartości"5.

Marketing sportu jest bardziej złożonym zagadnieniem. Andrzej Sznajder w swojej książce „Marketing sportu” przytacza dwie definicje tego pojęcia. Autorem jednej z nich jest L. Kesler, który w 1979 roku scharakteryzował je jako „działania producentów dóbr konsumpcyjnych, przemysłowych i usług uwzględniających sport jako narzędzie promocji" ${ }^{\prime}$. W tym artykule lepiej pojęcie marketingu sportu ilustruje jednak definicja sformułowana przez Guy'a Lewisa i Herba Appenzellera, którzy zwracali uwagę na dwa elementy tego zagadnienia: marketing sportu oraz marketing przez sport. Pierwszy z tych elementów rozumiany jest przez Lewisa i Appenzellera jako „wykorzystanie kompozycji narzędzi marketingowych do komunikowania się z konsumentami i wskazanie korzyści płynących z uprawiania sportu lub uczestniczenia w wydarzeniach sportowych". Marketing przez sport jest ich zdaniem terminem, gdzie sponsoring jest wykorzystywany jako narzędzie promocji ${ }^{7}$.

Celem tego artykułu jest analiza wizerunku Roberta Lewandowskiego w wybranych kampaniach promocyjno-reklamowych. Zostanie tu pokazana analiza łącznie 8 spotów następujących marek - Coca-Cola, Huawei, Nike oraz Vistula, w których polski sportowiec brał udział między 2011 a 2018 rokiem. Wybór takiej cezury czasowej jest spowodowany m.in. tym, że w 2011 roku piłkarz rozpoczął współpracę z marką Coca-Cola ${ }^{8}$. Niniejsza analiza będzie przeprowadzona również z perspektywy współczesnych wydarzeń, które odbywały się w 2021 roku. Dzięki temu będzie można spojrzeć na wizerunek kapitana reprezentacji Polski w wybranych kampaniach promocyjno-reklamowych w sposób wieloaspektowy. Analizy zawartości dokonano z użyciem sporządzonego wcześniej

${ }^{5}$ P. Kotler, G. Armstrong, J. Saunders, V. Wong, Marketing. Podręcznik europejski, tłum. L. Adamus, W. Kisiel, M. Woźniczka, Warszawa 2002, s. 39.

${ }^{6}$ Zob. A. Sznajder, Marketing sportu, Warszawa 2015, s. 25.

${ }^{7}$ Tamże, s. 25-26.

${ }^{8}$ tw, Robert Lewandowski twarzq Coca-Coli (wideo), „Wirtualnemedia.pl” z 20.04.2011 r., https://www.wirtualnemedia.pl/artykul/robert-lewandowski-twarza-coca-coli-wideo (dostęp: 23.04.2019 r.). 
klucza kategoryzacyjnego ${ }^{9}$, odnoszącego się do kilku kryteriów dotyczących sposobu ukazania postaci Lewandowskiego w danej reklamie. Każda z czterech marek, której reklamy z udziałem polskiego piłkarza są przedmiotem analizy, reprezentuje inną branżę (spożywczą, elektroniczną, sportową i odzieżową). Dlatego na ich przykładzie będzie można zobaczyć, jak w reklamach różnych marek - często niezwiązanych ze sportem - przedstawiany jest jego wizerunek.

\section{Niniejsza analiza będzie przeprowadzona również z perspektywy współczesnych wydarzeń, które odbywały się w 2021 roku. Dzięki temu będzie można spojrzeć na wizerunek piłkarza reprezentacji Polski w wybranych kampaniach promocyjno- reklamowych w sposób wieloaspektowy.}

Jak pisała w swojej książce Małgorzata Lisowska-Magdziarz, typowy klucz kategoryzacyjny jest złożony z części formalnej oraz części merytorycznej. Pierwsza z nich składa się z pytań dotyczących usytuowania badanych materiałów i ich cech formalnych, zaś w drugiej znajdują się pytania dotyczące treści tych materiałów ${ }^{10}$. Klucz opracowany na potrzeby tego artykułu składa się z 8 pytań. Kategorie, uwzględnione w pytaniach, dotyczą m.in. roku premiery danej reklamy z udziałem Roberta Lewandowskiego; roli, w jakiej występuje on w tych spotach (charakter postaci); otoczenia, w jakim jest on pokazany w reklamie; stylu jego ubioru w danej reklamie; czy emocji, które towarzyszą piłkarzowi Bayernu Monachium. Wyniki badań zostaną omówione w części dotyczącej analizowanych spotów reklamowych z jego udziałem.

${ }^{9}$ Szerzej reklamy z udziałem Roberta Lewandowskiego w oparciu o sporządzony wcześniej klucz kategoryzacyjny analizowałem w swojej pracy licencjackiej Piłkarz jako marka. Analiza potencjału marketingowego Roberta Lewandowskiego, napisanej pod kierunkiem dr Edyty Żyrek-Horodyskiej i obronionej w 2019 r. w Instytucie Dziennikarstwa, Mediów i Komunikacji Społecznej Uniwersytetu Jagiellońskiego.

${ }^{10}$ M. Lisowska-Magdziarz, Analiza zawartości mediów: przewodnik dla studentów: wersja 1.1, Kraków 2004, s. 56. 
Niezwykle istotne dla zbadania wizerunku polskiego sportowca w kampaniach wybranych marek będzie samo zdefiniowanie tego pojęcia. W książce „Public relations” Anthony'ego Davisa można przeczytać m.in., że „wizerunek” to „złożona intelektualna lub zmysłowa interpretacja, sposób postrzegania kogoś lub czegoś; wytwór umysłu wynikający z dedukcji opartej na dostępnych przesłankach, zarówno realnych, jak i wyobrażonych, uwarunkowany wrażeniami, przekonaniami, ideami i emocjami" ${ }^{\prime 1}$.

Według Eleri Sampson, wizerunek danego człowieka jest „wypracowaną mieszanką czynników wewnętrznych i zewnętrznych określających wizerunek własny, wizerunek widzialny i wizerunek pożądany". Natomiast wizerunek zewnętrzny ma jej zdaniem odpowiadać umiejętnościom, zdolnościom i wartościom, jakie reklamuje ${ }^{12}$. W swojej książce „Jak tworzyć własny wizerunek" Sampson wyróżniła także m.in. samodzielne elementy wizerunku własnego, które wspólnie tworzą całość, postrzeganą jako nasz wizerunek. Są to kategorie takie jak: wygląd, mowa ciała, opinia, postawa czy styl komunikowania ${ }^{13}$. Do niektórych z tych kategorii odnoszą się także kryteria uwzględnione we wspomnianym już kluczu kategoryzacyjnym, w oparciu o który przeprowadziłem w tym tekście analizę zawartości reklam z udziałem Roberta Lewandowskiego.

Krystyna Wojcik w książce „Public relations: od A do Z. Tom I” przytacza z kolei definicję, odnoszącą się do angielskiego terminu image (po polsku: „wizerunek”). Pojęcie to oznacza „wyobrażenie, jakie jedna lub wiele publiczności ma o osobie, przedsiębiorstwie lub instytucji". Warto przy tym zaznaczyć, że obraz, o którym jest mowa w tej definicji, nie jest rzeczywisty, lecz jest raczej mozaiką wielu szczegółów, które mogą być podchwycone m.in. przypadkowo czy fragmentarycznie ${ }^{14}$.

Tomasz Gackowski i Marcin Łączyński w książce „Metody badania wizerunku w mediach" w oparciu o definicje wizerunku, opracowywane przez kilku innych autorów, scharakteryzowali to pojęcie następująco: „wizerunek jest to reprezentacja jakiegoś przedmiotu (beneficjenta w naszym przypadku) w świadomości

\footnotetext{
${ }^{11}$ A. Davis, Public relations, Warszawa 2007, s. 47.

${ }^{12}$ E. Sampson, Jak tworzyć własny wizerunek, Warszawa 1996, s. 14-15.

${ }^{13}$ Tamże, s. 24-25.

${ }^{14}$ K. Wojcik, Public relations: od A do Z. Tom I, Warszawa 2001, s. 38.
} 
podmiotu (odbiorcy istotnego)". Wyróżnili oni także cztery przykładowe wymiary wizerunku: psychologiczny, socjologiczny, marketingowy i komunikacyjny ${ }^{15}$.

Powyższe definicje pokazują, że pojęcie wizerunku jest zagadnieniem wieloaspektowym i ściśle związanym z tym, w jaki sposób postrzegana jest przez odbiorców dana osoba.

\section{ROBERT LEWANDOWSKI W REKLAMACH}

Wyniki analizy zawartości z użyciem klucza kategoryzacyjnego

\begin{tabular}{|c|c|c|}
\hline Pytanie & Numer i oznaczenie kodu klucza & $\begin{array}{c}\text { Liczba } \\
\text { występujących } \\
\text { elementów }\end{array}$ \\
\hline \multirow[t]{4}{*}{ 1. Nazwa reklamowanej marki } & 101 Coca-Cola & 2 \\
\hline & 102 Huawei & 2 \\
\hline & 103 Nike & 2 \\
\hline & 104 Vistula & 2 \\
\hline \multirow{8}{*}{$\begin{array}{l}\text { 2. Rok, w którym ukazała się reklama } \\
\text { z Robertem Lewandowskim }\end{array}$} & 201 rok 2011 & 0 \\
\hline & 202 rok 2012 & 0 \\
\hline & 203 rok 2013 & 0 \\
\hline & 204 rok 2014 & 1 \\
\hline & 205 rok 2015 & 2 \\
\hline & 206 rok 2016 & 2 \\
\hline & 207 rok 2017 & 1 \\
\hline & 208 rok 2018 & 2 \\
\hline \multirow[t]{2}{*}{ 3. Czy pojawia się on w reklamie sam? } & 301 tak & 3 \\
\hline & 302 nie & 5 \\
\hline \multirow{4}{*}{$\begin{array}{l}\text { 4. Jeśli } 302 \text {, kto jeszcze pojawia się } \\
\text { w reklamie? }\end{array}$} & 401 inni sportowcy & 3 \\
\hline & 402 rodzina piłkarza & 1 \\
\hline & 403 celebryci & 0 \\
\hline & 404 zwykli ludzie & 3 \\
\hline
\end{tabular}

${ }^{15}$ T. Gackowski, M. Łączyński (red.), Metody badania wizerunku w mediach, Warszawa 2009, s. 81-82. 


\begin{tabular}{|c|c|c|}
\hline \multirow{7}{*}{$\begin{array}{l}\text { 5. Otoczenie, w jakim w reklamie poka- } \\
\text { zany jest Robert Lewandowski }\end{array}$} & 501 boisko piłkarskie & 3 \\
\hline & 502 miasto & 2 \\
\hline & 503 wieś & 0 \\
\hline & 504 środowisko domowe - łazienka & 1 \\
\hline & $\begin{array}{c}505 \text { środowisko domowe - salon/pokój } \\
\text { dzienny }\end{array}$ & 1 \\
\hline & 506 studio nagraniowe & 1 \\
\hline & 507 inne & 3 \\
\hline \multirow{3}{*}{$\begin{array}{l}\text { 6. W jaki strój jest ubrany Robert } \\
\text { Lewandowski? }\end{array}$} & 601 strój piłkarski & 3 \\
\hline & 602 strój codzienny & 5 \\
\hline & 603 strój formalny & 2 \\
\hline \multirow{6}{*}{$\begin{array}{l}\text { 7. Charakter postaci Roberta Lewan- } \\
\text { dowskiego w danej reklamie }\end{array}$} & 701 piłkarz & 4 \\
\hline & 702 wzór do naśladowania & 3 \\
\hline & 703 zwykły człowiek & 3 \\
\hline & 704 sportowiec & 5 \\
\hline & 705 biznesmen & 0 \\
\hline & 706 inne & 0 \\
\hline \multirow{8}{*}{$\begin{array}{l}\text { 8. Emocje towarzyszące Robertowi Le- } \\
\text { wandowskiemu w danej reklamie }\end{array}$} & 801 koncentracja & 2 \\
\hline & 802 zdenerwowanie & 0 \\
\hline & 803 determinacja & 2 \\
\hline & 804 radość & 3 \\
\hline & 805 smutek & 0 \\
\hline & 806 zaskoczenie & 0 \\
\hline & 807 ulga & 0 \\
\hline & 808 pewność siebie & 7 \\
\hline
\end{tabular}

Źródło: Opracowanie własne na podstawie wyników dokonanej analizy.

Dokonana analiza dotyczyła łącznie 8 wybranych spotów marek, w których na przestrzeni lat 2011-2018 udział brał Robert Lewandowski. W 2015, 2016 i 2018 roku ukazało się łącznie 6 reklam (po dwie w każdym wymienionym roku). Natomiast dwa pozostałe spoty miały swoją premierę w roku 2014 i 2017. Polak w 3 badanych reklamach występuje sam, natomiast w pozostałych pięciu 
towarzyszą mu inne osoby. Są to inni sportowcy (w 3 reklamach), rodzina piłkarza (1 reklama) czy zwykli ludzie, np. kibice piłkarscy (3 reklamy).

Otoczeniem, w jakim w tych reklamach był pokazany kapitan polskiej kadry, było najczęściej (3 razy) boisko piłkarskie albo „inne” otoczenie - góry, inna otwarta przestrzeń lub biurowiec. Dwukrotnie piłkarz był pokazany w otoczeniu typowo miejskim, a po 1 razie takim otoczeniem była domowa łazienka, domowy salon czy studio nagraniowe.

Jeżeli chodzi o ubiór zawodnika Bayernu Monachium, najczęściej, bo w 5 spotach prezentował się $\mathrm{w}$ codziennych stylizacjach; trzykrotnie - $\mathrm{w}$ stroju piłkarskim (np. stroju reprezentacji Polski); a dwukrotnie - w stroju formalnym (np. garnitur). Ubrania, które w reklamach danych marek miał na sobie Lewandowski, często odpowiadały wartościom, jakie promował.

Pięciokrotnie był on przedstawiany w reklamie jako piłkarz i sportowiec, a trzykrotnie jako wzór do naśladowania czy zwykły człowiek. Emocją, która najczęściej towarzyszyła mu w badanych przekazach reklamowych, była pewność siebie (w 7 reklamach); w trzech przypadkach radość, a w dwóch - koncentracja lub determinacja.

\section{REKLAMY MARKI COCA-COLA}

Współpraca Lewandowskiego z marką Coca-Cola rozpoczęła się, gdy grał jeszcze w Borussii Dortmund. Kontrakt z producentem napojów gazowanych miał obowiązywać w 2011 i 2012 roku oraz obejmować m.in. działania, które towarzyszyły rozgrywanym w Polsce i na Ukrainie mistrzostwom Europy w 2012 roku. Oprócz tego, polski piłkarz został także ambasadorem piłkarskiego turnieju dla młodzieży Coca-Cola Cup ${ }^{16}$.

W czerwcu 2014 roku premierę miała reklama marki Coca-Cola, związana z finałami piłkarskich mistrzostw świata, w której pojawili się Robert Lewandowski oraz były znakomity polski piłkarz Zbigniew Boniek. Sam spot miał pokazywać markę jako sponsora futbolu i licznych wydarzeń sportowych ${ }^{17}$. W reklamie

\footnotetext{
${ }^{16}$ tw, Robert Lewandowski twarzq..., dz. cyt.

17 tw, Coca-Cola spotem z Bońkiem i Lewandowskim reklamuje się jako sponsor piłki nożnej (wideo), „Wirtualnemedia.pl” z 16.06.2014 r., https://www.wirtualnemedia.pl/artykul/cocacola-spotem-z-bonkiem-i-lewandowskim-reklamuje-sie-jako-sponsor-pilki-noznej-wideo (dostęp: 23.04.2019 r.).
} 
obok ujęć przypominających występy Polaków na mundialu w 1982 roku w Hiszpanii, widzimy migawki z finału turnieju Coca-Cola Cup z 2013 roku w Krakowie. Pojawia się na nich Robert Lewandowski, podpisujący autografy na koszulkach. Historia zawarta w reklamie jest opatrzona komentarzem lektora wspominającego o tym, iż nie przypuszczano, że futbol będzie tak znaną dyscypliną, uprawianą codziennie przez 270 milionów osób na świecie, a sukcesy osiągane w przeszłości przez polską reprezentację są inspiracją dla wielu tysięcy młodych ludzi, biorących udział w turniejach takich jak Coca-Cola Cup. W reklamie zwrócono uwagę na to, że marka wspiera nie tylko mistrzostwa świata, ale również turnieje dla początkujących piłkarzy. Na koniec słyszymy zdanie mówiące, że jedna mała akcja może zainspirować wiele innych, a po chwili możemy zobaczyć hasztag z hasłem, które towarzyszyło kampanii, czyli „Ruch to szczęście”"18.

Obok Lewandowskiego w reklamie widoczni są również inni piłkarze, młodzi zawodnicy czy kibice. Wspieranie mundialu przez Coca-Colę lub bycie sponsorem tytularnym turnieju Coca-Cola Cup możemy określić jako przykłady marketingu przez sport, czyli wykorzystywania sponsoringu jako narzędzia promocji ${ }^{19}$. Obecność Lewandowskiego w tej reklamie w roli ambasadora turnieju Coca-Cola Cup może tworzyć wśród odbiorców obraz jego osoby jako sportowca, promującego rozgrywki dla młodzieży i wspierającego takie działania. To z kolei oznacza, że zewnętrzny wizerunek Lewandowskiego odpowiada wartościom, jakie w tym spocie reklamuje.

W 2017 roku kapitan reprezentacji Polski uczestniczył w reklamie napoju Coca-Cola Zero Cukru. W trwającym trzydzieści sekund spocie tłum kibiców oczekuje na Lewandowskiego i na otrzymanie autografu od niego. Jeden z fanów, czekających w kolejce, zauważa w oknie sklepowej witryny reklamę produktu Coca-Cola Zero Cukru, po czym idzie do sklepu, by kupić produkt i orzeźwić się napojem. Po chwili młody mężczyzna wraca do oczekujących. Zamiast kartki w ręce trzyma butelkę Coca-Coli, którą wystawia, by Lewandowski złożył na niej swój podpis. Piłkarz robi to, po czym odchodzi. Chwilę później młody fan wypija pozostałą zawartość butelki z napojem i zauważa na jej powierzchni autograf piłkarza.

${ }^{18}$ [b.a.], Coca-Cola spotem z Bońkiem i Lewandowskim reklamuje się jako sponsor piłki nożnej, „Tv.wirtualnemedia.pl” z 12.06.2014 r., http://tv.wirtualnemedia.pl/film/coca-cola-spotem-z-bonkiem-i-lewandowskim-reklamuje-sie-jako-sponsor-pilki-noznej (dostęp: 24.04.2019 r.).

${ }^{19}$ Zob. A. Sznajder, dz. cyt. s. 26. 
Sportowiec macha do niego ręką, odjeżdżając samochodem razem z towarzyszącą mu ochroną ${ }^{20}$.

Warto zaznaczyć, że na początku 2018 roku ogłoszono zakończenie współpracy między Coca-Colą a Lewandowskim. Było to spowodowane wygaśnięciem wraz z końcem 2017 roku poprzedniego kontraktu reklamowego. Przed wypełnieniem do końca terminu umowy, na polskiego piłkarza spadła też fala krytyki ze strony wielu internautów, zarzucających mu, że reklamowanie napoju Coca-Cola Zero Cukru nie jest całkowicie spójne ze sportowym stylem życia, promowanym przez niego i jego żonę, Annę ${ }^{21}$. Podobnego zdania była część ekspertów, których opinie opublikowano w sierpniu 2017 roku na łamach portalu Wirtualnemedia.pl ${ }^{22}$.

Temat promowania przez sportowców produktów marek takich jak Coca-Cola czy utożsamiania ich z niezdrowym stylem życia powrócił w czerwcu 2021 roku - podczas piłkarskich mistrzostw Europy. Na konferencji prasowej przed meczem Portugalia-Węgry jeden z czołowych piłkarzy świata, Cristiano Ronaldo, zabrał ze stołu konferencyjnego dwie butelki Coca-Coli i postawił je z dala od swojego mikrofonu. Chwilę później wziął do ręki butelkę wody mineralnej i zaapelował do osób obecnych na sali, aby pili wodę 23 .

Zachowanie Portugalczyka, który słynie ze zdrowego stylu życia, a w wywiadach wspominał m.in., że jest zły na swojego syna Cristiano Ronaldo Juniora, gdy ten pije colę lub podobne napoje ${ }^{24}$, nie może więc dziwić. Wywołało ono jednak poruszenie z uwagi na fakt, że marka Coca-Cola była jednym ze sponsorów mistrzostw

${ }^{20}$ jd, Robert Lewandowski twarza kampanii Coca-Cola Zero Cukru, „Wirtualnemedia.pl” z 7.08.2017 r., https://www.wirtualnemedia.pl/artykul/robert-lewandowski-reklama-cocacola-zero-cukru-wideo (dostęp: 24.04.2019 r.).

${ }^{21}$ B. Goczał, Robert Lewandowski zakończył współpracę z marką Coca-Cola, „,Wirtualnemedia. pl" z 10.01.2018 r., https://www.wirtualnemedia.pl/artykul/robert-lewandowski-zrezygnujez-reklam-marki-coca-cola-koniec-umowy (dostęp: 24.04.2019 r.).

${ }^{22}$ B. Goczał, Robert Lewandowski w reklamie Coca-Coli Zero Cukru: słuszny wybór czy marketingowa rysa na wizerunku sportowca? (opinie), „Wirtualnemedia.pl” z 8.08.2017 r., https://www.wirtualnemedia.pl/artykul/robert-lewandowski-w-reklamie-coca-coli-zerosluszny-wybor-marketera-czy-marketingowa-rysa-na-wizerunku-sportowca-opinie (dostęp: 6.11.2021 r.).

${ }^{23}$ KowS, Ronaldo zaszokował swoich zachowaniem na konferencji. I wypowiedział dwa słowa, „Sport.pl” z 15.06.2021 r., https://www.sport.pl/euro/7,154862,27203465,ronaldo-podpadl-sponsorowi-euro-2020-uefa-nie-bedzie-zadowolona.html (dostęp: 30.10.2021r.)

${ }^{24}$ J. P. Gwizdek, Cristiano Ronaldo surowy wobec syna. "Kiedy pije cole, jestem na niego zły", „Sport.tvp.pl” z 29.12.2020 r., https://sport.tvp.pl/51550577/cristiano-ronaldo-jestem-zlyna-syna-kiedy-pije-coca-cole (dostęp: 3.11.2021 r.) 
Europy. W związku z tym mogła ona lokować swoje produkty w czasie turnieju. Zdaniem ekspertów wypowiadających się niedługo po tych wydarzeniach dla portalu Wirtualnemedia.pl, ten gest mógł być m.in. przykładem braku zgody sportowca na utożsamianie go z napojem kojarzącym się z niezdrowym stylem życia ${ }^{25}$.

Temat promowania przez sportowców produktów marek takich jak Coca-Cola czy utożsamiania ich z niezdrowym stylem życia powrócił w czerwcu 2021 roku - podczas piłkarskich mistrzostw Europy. Na konferencji prasowej przed meczem Portugalia-Węgry jeden z czołowych piłkarzy świata, Cristiano Ronaldo, zabrał ze stołu konferencyjnego dwie butelki Coca-Coli i postawił je z dala od swojego mikrofonu. Chwilę później wziął do ręki butelkę wody mineralnej i zaapelował do osób obecnych na sali, aby pili wodę.

W kontekście tych wydarzeń, można zastanawiać się czy wybór Lewandowskiego na osobę reklamującą w 2017 roku produkt Coca-Cola Zero Cukru, był słusznym kierunkiem. Nawiązując do opisywanego przez Eleri Sampson wizerunku zewnętrznego, można stwierdzić, że wizerunek zewnętrzny zawodnika Bayernu Monachium, który na co dzień promuje zdrowy styl życia, nie do końca odpowiadał wartościom, jakie reklamuje w spocie związanym z produktem marki Coca-Cola ${ }^{26}$. Z perspektywy marki można to uznać za niezbyt trafiony wybór bohatera reklamy. Natomiast ze strony wizerunkowej, odnosząc się choćby do

${ }^{25}$ J. Dąbrowska-Cydzik, Cristiano Ronaldo wzgardził Coca-Colq na konferencji prasowej. "Niezgoda na promowanie niezdrowego stylu życia”, „Wirtualnemedia.pl” z 16.06.2021 r., https://www.wirtualnemedia.pl/artykul/cristiano-ronaldo-bojkot-coca-cola-wybiera-wodakryzys-wizerunkowy (dostęp: 3.11.2021 r.)

${ }^{26}$ Zob. E. Sampson, dz. cyt., s. 14-15. 
przytaczanej przez Krystynę Wojcik definicji image' $u^{27}$, może to budzić u odbiorców na swój sposób mylące wyobrażenie o osobie polskiego piłkarza.

\section{REKLAMY MARKI HUAWEI}

Pod koniec 2015 roku Robert Lewandowski został ogłoszony ambasadorem jednego z czołowych przedstawicieli branży elektronicznej - marki Huawei ${ }^{28}$. Istotą tej funkcji według Andrzeja Sznajdera jest „dążenie do kojarzenia określonej marki ze znanym i lubianym sportowcem osiągającym sukcesy”29. Inną, bardziej ogólną definicję terminu „ambasador marki” znajdziemy z kolei w książce „Kreowanie marki korporacyjnej” Magdaleny Daszkiewicz i Sylwii Wrony. Według nich, ten termin oznacza bycie „znaną osobą, której wizerunek jest związany z marką ze względu na jej styl życia"30.

Ta ostatnia definicja znajduje swoje odbicie już w pierwszym spocie reklamowym Huawei, w którym pojawił się Lewandowski. Trwająca nieco ponad minutę reklama przedstawia drogę piłkarza do sukcesu. Reprezentant Polski opowiada o przeszkodach, jakie musiał pokonywać na początku kariery, by spełnić swoje marzenie z dzieciństwa o byciu profesjonalnym piłkarzem. Oprócz tych ujęć pojawiają się retrospekcje inspirowane wydarzeniami z młodości Lewandowskiego oraz zdjęcia piłkarza i jego najbliższych, które są wyświetlane na smartfonie marki Huawei. Na zakończenie sportowiec, trzymając w prawej ręce telefon, wypowiada hasło Make it Possible (po polsku: „Uczyń to możliwym”), czyli główne hasło reklamowe koncernu Huawei ${ }^{31}$. Spot pojawił się m.in. na profilu Lewandowskiego na Facebooku - w wersji anglojęzycznej ukazał się 30 listopada tego samego roku ${ }^{32}$.

${ }^{27}$ Zob. K. Wojcik, dz. cyt., s. 38.

${ }^{28} \mathrm{tw}$, Robert Lewandowski międzynarodowym ambasadorem reklamowym Huawei, ,Wirtualnemedia.pl" z 10.11.2015 r., https://www.wirtualnemedia.pl/artykul/robert-lewandowskimiedzynarodowym-ambasadorem-reklamowym-huawei (dostęp: 21.04.2019 r.).

${ }^{29}$ A. Sznajder, dz. cyt., s. 34 .

${ }^{30}$ M. Daszkiewicz, S. Wrona, Kreowanie marki korporacyjnej, Warszawa 2014, s. 111.

${ }^{31}$ tw, Droga Roberta Lewandowskiego do sukcesu w spocie Huawei (wideo), „Wirtualnemedia.pl” z 17.11.2015 r., https://www.wirtualnemedia.pl/artykul/droga-robertalewandowskiego-do-sukcesu-w-spocie-huawei-wideo (dostęp: 18.04.2019 r.).

${ }^{32}$ Make it Possible. See my story, search for inspiration to begin your own!, „Facebook. com" z 30.11.2015 r., https://www.facebook.com/watch/?v=1041310035914384 (dostęp: 15.04.2021 r.). 
Oprócz polskiego piłkarza w reklamie pojawiają się przeważnie aktorzy bądź statyści, odgrywający role Lewandowskiego lub innych zawodników czy bliskich gracza Bayernu Monachium. Na zdjęciach, przeglądanych przez reprezentanta Polski, można zobaczyć jego rodziców. Akcja spotu reklamowego rozgrywa się w takich miejscach jak boiska piłkarskie, szatnia, miasto czy podwórko. Sama reklama zawiera również chwytliwe i motywujące hasło Make it Possible, mogące pełnić funkcję perswazyjną oraz zachęcać odbiorców do zakupu smartfonów marki Huawei pod pretekstem tego, że dzięki zakupieniu tego telefonu będą oni mogli realizować swoje pasje i marzenia - tak jak miało to miejsce w przypadku Lewandowskiego ${ }^{33}$.

Opowieść piłkarza o swojej drodze do sukcesu i połączenie jej w reklamie z mottem przewodnim całej kampanii, pokazującym, iż wszystko jest możliwe, jest znakomitym przykładem tego, że zewnętrzny wizerunek zawodnika Bayernu Monachium odpowiada wartościom, które są reklamowane w spocie marki Huawei.

\section{Opowieść piłkarza o swojej drodze do sukcesu i połączenie jej w reklamie z mottem przewodnim całej kampanii, pokazującym, iż wszystko jest możliwe, jest znakomitym przykładem tego, że zewnętrzny wizerunek zawodnika Bayernu Monachium odpowiada wartościom, które są reklamowane w spocie marki Huawei.}

Pod koniec 2018 roku polski piłkarz pojawił się także m.in. w kampanii promującej inny z modeli smartfonów marki Huawei - Mate20 Pro. W reklamie siedzi on za kierownicą luksusowego, sportowego samochodu. Można dostrzec w niej ważne elementy specyfikacyjne telefonu - odblokowywanie ekranu za pomocą wzroku, czytnik linii papilarnych w ekranie czy wydajny procesor. Dzięki użyciu

${ }^{33}$ Z. Bajka, Krótka historia reklamy na świecie i w Polsce, „Zeszyty Prasoznawcze” $1993 \mathrm{nr}$ 3-4, s. 37. 
sztucznej inteligencji oraz nawigacji obecnej w smartfonie, Lewandowski bez trudu zatrzymuje się przed szczytem urwiska, po czym wysiada z samochodu i wykonuje zdjęcia rozpościerającego się dookoła krajobrazu ${ }^{34}$.

Odbiorca widzący tę reklamę może stwierdzić, że tak zaprezentowany smartfon jest wart zakupu ze względu na to, iż będzie on niezawodny w każdej sytuacji. Lewandowski w trakcie reklamy wydaje pewne polecenia pojazdowi, który prowadzi. Hasło takie jak „pełna moc” nawiązuje m.in. do wydajności procesora reklamowanego smartfonu. Pokazanie przez piłkarza zalet tego urządzenia i sposób, w jaki to zrobił, świadczy o tym, że jego zewnętrzny wizerunek odpowiada reklamowanym przez niego wartościom.

\section{REKLAMY MARKI NIKE}

Kolejną z marek, które reklamował Robert Lewandowski, była marka Nike, czyli jeden z potentatów wśród firm reprezentujących branżę sportową. Jedna z pierwszych kampanii tej marki z udziałem polskiego piłkarza ruszyła już w 2012 roku. Nosiła ona nazwę „To jest mój czas”, a działania reklamowe miały związek ze zbliżającymi się wówczas mistrzostwami Europy w Polsce i na Ukrainie. W pełnej wersji reklamy, trwającej trzy minuty, wystąpili m.in. tacy piłkarze jak Cristiano Ronaldo i Neymar, ale też chociażby amerykański koszykarz LeBron James. Spot był interaktywny. Po jego obejrzeniu odbiorcy mogli uruchomić i obejrzeć inne nagrania, w których zawodnicy opowiadali o swoich doświadczeniach. Bohaterem jednego z takich nagrań był m.in. także Lewandowski ${ }^{35}$.

Reklamą marki Nike, gdzie widoczny był wizerunek tylko polskiego piłkarza, był animowany spot z 2015 roku, promujący najnowszy model obuwia piłkarskiego - Nike Hypervenom. Reklamę z udziałem Polaka, która nazywała się Nike Hypervenom: Robert Lewandowski. Sense the chance, strike before they realise (po polsku: "Nike Hypervenom: Robert Lewandowski. Wyczuj szansę, strzel, zanim się zorientują"), można było zobaczyć w telewizji bądź w serwisie YouTube. Spot

${ }^{34}$ tw, Robert Lewandowski w samochodzie reklamuje Huawei Mate20 Pro (wideo), „Wirtualnemedia.pl" z 3.12.2018 r., https://www.wirtualnemedia.pl/artykul/huawei-mate20-prosmartfony-reklama-robert-lewandowski-w-samochodzie-wideo (dostęp: 23.04.2019 r.).

${ }^{35}$ T. Wojtas, „To jest mój czas” - Nike rusza z kampaniq na Euro 2012 (wideo), „Wirtualnemedia.pl" z 21.05.2012 r., https://www.wirtualnemedia.pl/artykul/to-jest-moj-czas-nikerusza-z-kampania-na-euro-2012-wideo (dostęp: 23.04.2019 r.). 
ten na potrzeby rynku polskiego zyskał również dodatkowe hasło - „Hypervenom. Zwodniczy z natury" ${ }^{36}$.

W trwającej niespełna dwadzieścia sekund reklamie, zamieszczonej w serwisie YouTube i zrealizowanej w języku angielskim, widać, jak Lewandowski uwalnia się spod opieki obrońców, po czym kieruje piłkę do bramki w spektakularny sposób. Czyni to, grając w reklamowanych butach piłkarskich Nike ${ }^{37}$.

W maju 2016 roku swoją premierę miała z kolei reklama Pokolenie Lewandowskiego. W ramach tego projektu powstał trzydziestosekundowy spot, podczas którego można zobaczyć różne osoby trenujące piłkę nożną. Działania promocyjne, mające związek z tą reklamą, prowadzone były na facebookowych profilach marki Nike i Roberta Lewandowskiego, ale też w telewizji. W reklamie wystąpili m.in. zawodowi piłkarze tacy jak Arkadiusz Milik, Bartosz Kapustka czy Ewa Pajor. Jednym z elementów klipu było jedno słowo, pojawiające się przy każdej postaci i charakteryzujące tę osobę. Te wyrazy to np.: snajper, perfekcjonista czy pionier. Inspiracją do rozpoczęcia przygody z piłką nożną dla wszystkich bohaterów był właśnie Robert Lewandowski ${ }^{38}$. Pojawia się on w szatni piłkarskiej, ale trudno ocenić, jakie emocje mu towarzyszą. Można przypuszczać, że jest skoncentrowany.

Przez pryzmat tych dwóch reklam odbiorca może postrzegać Lewandowskiego jako skutecznego piłkarza, który jest jednocześnie inspiracją oraz swoistym mentorem dla innych zawodników. Wskazuje na to chociażby wyraz „lider”, widniejący obok postaci kapitana naszej drużyny narodowej pod koniec spotu „Pokolenie Lewandowskiego" ${ }^{\prime 39}$. To słowo wzmacnia przekaz i może pomóc kształtować taki wizerunek piłkarza w umyśle odbiorcy.

${ }^{36}$ bg, Rysunkowy Robert Lewandowski w reklamie butów Nike (wideo), „Wirtualnemedia.pl” z 18.08.2015 r., https://www.wirtualnemedia.pl/artykul/rysunkowy-robert-lewandowskiw-reklamie-butow-nike-wideo (dostęp: 22.04.2019 r.).

${ }^{37}$ Nike Hypervenom: Robert Lewandowski. Sense the chance, strike before they realise., „Youtube.com” (brak daty opubl.), https://www.youtube.com/watch?v=vUoa0f5i0xo\&t=6s (dostęp: 23.04.2019 r.). Na dzień 15.04.2021 roku, po otworzeniu tego linku, film widnieje w serwisie YouTube jako „film prywatny”. Brakuje też informacji o dacie opublikowania tego filmu (dostęp: 15.04.2021 r.).

${ }^{38}$ bg, „Pokolenie Lewandowskiego” w piłkarskiej kampanii Nike (wideo), „Wirtualnemedia.pl" z 6.05.2016 r., https://www.wirtualnemedia.pl/artykul/pokolenie-lewandowskiegow-pilkarskiej-kampanii-nike-wideo (dostęp: 20.04.2019 r.).

${ }^{39}$ Tamże. 


\section{REKLAMY MARKI VISTULA}

Vistula to polska marka odzieżowa, produkująca przede wszystkim stroje formalne, takie jak garnitury. W marcu 2016 roku stała się ona także oficjalnym partnerem Polskiego Związku Piłki Nożnej ${ }^{40}$. W ramach tej współpracy powstała m.in. specjalna kolekcja garniturów, płaszczy, koszul i obuwia, w której zawodnicy reprezentacji Polski, prowadzonej wówczas przez Adama Nawałkę, mieli pojechać na finały piłkarskich mistrzostw świata do Rosji w 2018 roku. Garnitury z tej kolekcji można było później kupić w stacjonarnych salonach Vistuli oraz w sklepie internetowym tej marki ${ }^{41}$.

W 2016 roku ambasadorem reklamowym Vistuli został Robert Lewandowski. Podczas sesji zdjęciowej zrealizowanej w Monachium, polski piłkarz promował ubrania tej marki ${ }^{42}$. W marcu 2016 roku kapitan polskiej kadry wystąpił w reklamie Vistuli. W trzydziestosekundowym spocie opublikowanym w serwisie YouTube 17 marca 2016 roku przegląda on się w lustrze, po czym zmierza w kierunku domowej garderoby i wybiera koszulę zapinaną na spinki, garnitur, krawat oraz obuwie. Na zakończenie sportowiec kopie piłkę w kierunku nagrywającej to ujęcie kamery i wypowiada słowa, będące motywem przewodnim całej reklamy: Vistula. Mój wybór, mój styl. - Robert Lewandowski ${ }^{43}$.

Spot opublikowany został także na profilu marki Vistula na Facebooku w tym samym dniu co reklama w serwisie YouTube ${ }^{44}$. Klip promował linię ubrań, nazwaną SELECTION, która była kolekcją wybraną przez samego Lewandowskiego. Można ją było znaleźć w części salonów Vistuli na terenie Polski ${ }^{45}$.

${ }^{40}$ PZPN, PZPN podpisał umowe z firma Vistula Group SA, oficjalny serwis Polskiego Związku Piłki Nożnej z 10.03.2016 r., https://www.pzpn.pl/federacja/aktualnosci/2016-03-10/ pzpn-podpisal-umowe-z-firma-vistula-group-sa (dostęp: 10.12.2021 r.).

${ }^{41} \mathrm{jd}$, Vistula przygotowała formalne stroje dla piłkarskiej reprezentacji Polski na Mundial, „Wirtualnemedia.pl” z 27.04.2018 r., https://www.wirtualnemedia.pl/artykul/pilkarskareprezentacja-polski-stroje-mundial-rosja-2018 (dostęp: 24.04 .2019 r.).

${ }^{42} \mathrm{bg}$, Robert Lewandowski bohaterem kampanii reklamowej Vistuli, „Wirtualnemedia.pl” z 18.02.2016 r., https://www.wirtualnemedia.pl/artykul/robert-lewandowski-bohateremkampanii-reklamowej-vistuli (dostęp: 23.04.2019 r.).

${ }^{43}$ Vistula. Mój wybór, mój styl. - Robert Lewandowski, „Youtube.com” z 17.03.2016 r., https://www.youtube.com/watch?v=EAnQKgSohoA (dostęp: 23.04.2019 r.).

44 „Vistula. Mój wybór, mój styl” - Robert Lewandowski., „Facebook.com” z 17.03.2016 r., https://www.facebook.com/vistulathemensworld/videos/1074055715951267/ (dostęp: 9.06.2019 r.).

${ }^{45}$ Portal gpr24.pl, Mój wybór, mój styl - Robert Lewandowski dla Vistuli, „Głos Pruszkowa” z 22.03.2016 r., https://gpr24.pl/artykul/moj-wybor-moj-styl-robert-lewandowski-dlavistuli/354363 (dostęp: 23.04.2019 r.). 
Piłkarz wziął udział m.in. także w kampanii promującej sygnowaną jego nazwiskiem jesienno-zimową kolekcję odzieży na sezon 2018/2019. Linia ubrań miała odpowiadać wymaganiom współczesnego mężczyzny, „którego praca i intensywny styl życia generują nowe, ambitne potrzeby i oczekiwania"46. Na potrzeby tej kampanii powstał także trzydziestosekundowy spot reklamowy, promujący kolekcję. Został on opublikowany w serwisie YouTube 25 października 2018 roku. Jego akcja rozgrywa się $\mathrm{w}$ zimowej scenerii, prawdopodobnie w górach. W takich okolicznościach przyrody można zobaczyć zawodnika Bayernu, który prezentuje się w różnych stylizacjach, inspirowanych ubraniami z najnowszej kolekcji marki Vistula. Pojawia się on m.in. w dopasowanych garniturach czy stylowym płaszczu ${ }^{47}$.

Oba spoty odzwierciedlają to, co o wizerunku zewnętrznym pisała Eleri Sampson. Styl ubioru piłkarza w reklamie z 2016 roku i wykorzystanie w niej elementu piłki nożnej sprawiają, że odbiorcy mogą postrzegać go jako sportowca, ceniącego elegancję. Jednocześnie odpowiednia prezencja i nienaganny ubiór, zaprezentowany w spotach marki produkującej odzież formalną, bardzo mocno uwiarygadnia przekaz i pokazuje (w nawiązaniu do tego, o czym pisała Sampson), że wizerunek zewnętrzny kapitana polskiej kadry w pełni odpowiada wartościom, które reklamuje ${ }^{48}$.

Podsumowując wyniki dokonanej przeze mnie analizy, jak i omówienie poszczególnych reklam, Lewandowski bardzo często przedstawiany jest w nich jako sportowiec, co koreluje z wykonywanym przez niego zawodem profesjonalnego piłkarza. W spotach często wykazywał się m.in. pewnością siebie, czyli jednym $\mathrm{z}$ aspektów elementu wizerunku własnego, opisywanego przez Sampson jako „postawa”49. Jest to jednocześnie bardzo ważny czynnik, który może być pomocny w procesie budowania własnego wizerunku przez gracza Bayernu Monachium.

${ }^{46}$ tw, Robert Lewandowski promuje jesienno-zimowq kolekcję Vistuli (wideo), „Wirtualnemedia.pl" z 26.10.2018 r., https://www.wirtualnemedia.pl/artykul/vistula-kolekcja-robert-lewandowski-jesien-zima-2018-2019 (dostęp: 22.04.2019 r.).

${ }^{47}$ Robert Lewandowski Collection JZ18/19, „Youtube.com” z 25.10.2018 r., https://www. youtube.com/watch?v=Ksr33MrRtHs (dostęp: 20.04.2019 r.).

${ }^{48}$ Zob. E. Sampson, dz. cyt., s. 14-15.

${ }^{49}$ Tamże, s. 25. 


\section{ROBERT LEWANDOWSKI - REKLAMY A AKTYWNOŚĆ W MEDIACH SPOŁECZNOŚCIOWYCH}

\section{Analiza profilu Roberta Lewandowskiego na Facebooku}

Do analizy profilu kapitana reprezentacji Polski na Facebooku i zbadania sposobu reklamowania tam poszczególnych produktów posłużą posty związane z marką Huawei, publikowane między listopadem 2015 a grudniem 2018 roku. Zastosowanie takiej cezury czasowej spowodowane jest tym, że w listopadzie 2015 roku piłkarz został ogłoszony ambasadorem tej marki ${ }^{50}$.

Pierwszy post związany z osobą Roberta Lewandowskiego i koncernem z branży elektronicznej pojawił się na facebookowym profilu polskiego piłkarza 9 listopada 2015 roku. Obwieszczał on nawiązanie przez gracza Bayernu Monachium współpracy z Huawei Consumer Polska. Na zdjęciu można zobaczyć ubranego w garnitur Lewandowskiego, który trzyma w rękach smartfon (prawdopodobnie jest to jeden z modeli wyprodukowanych przez markę Huawei) i logotyp marki, opatrzony podpisem „Gramy razem!”1

Przedstawienie takiego hasła na tym zdjęciu - podobnie jak użyty w innej reklamie Huawei z Lewandowskim slogan Make it Possible może spełniać w pewnym stopniu funkcję perswazyjną ${ }^{52}$. Zmniejszenie dystansu poprzez użycie pierwszej osoby liczby mnogiej w opisie załączonym do postu, może być elementem pozwalającym poczuć odbiorcy bliską więź z marką, którą reklamuje Lewandowski.

W badanym okresie na profilu piłkarza Bayernu Monachium pojawiło się łącznie 36 postów, które w jakikolwiek sposób były związane z marką Huawei. Najczęściej przedstawiały one filmy, będące często przykładami reklam poszczególnych produktów takich jak smartfony. Tego rodzaju posty ukazywały się aż 25 razy. Jedenaście pozostałych wpisów opatrzonych było pojedynczymi zdjęciami (lub ich serią) albo służyły do udostępnienia fotografii na koncie polskiego piłkarza na Instagramie. 2019 r.).

${ }^{50}$ tw, Robert Lewandowski międzynarodowym ambasadorem..., dz. cyt. (dostęp: 21.04.

${ }^{51}$ Post z 9 listopada 2015 roku na profilu Roberta Lewandowskiego na Facebooku, promujący markę Huawei, „Facebook.com” z 9.11.2015 r., https://www.facebook.com/rl9official/ photos/a.295391460506249/1031632156882172/?type=3\&theater (dostęp: 10.05.2019 r.).

${ }^{52}$ Z. Bajka, art. cyt., s. 37. 
Obserwacje dotyczące postów, publikowanych na profilu Roberta Lewandowskiego na Facebooku i związanych z marką Huawei pokazują ich różnorodność, jeśli chodzi o wykorzystywaną tam formę przekazu - dominują tu głównie filmy, będące często spotami reklamowymi.

\section{Analiza profilu Roberta Lewandowskiego na Instagramie}

Pierwszy post na koncie Lewandowskiego na Instagramie ukazał się 10 stycznia 2014 roku $^{53}$. Oprócz zdjęć z meczów czy ujęć przedstawiających chwile z życia prywatnego, na jego profilu często można znaleźć posty związane z markami, które reklamuje. Przedmiotem analizy wizerunku polskiego piłkarza w kampaniach promocyjno-reklamowych na Instagramie, będą - tak jak w przypadku Facebooka - posty dotyczące marki Huawei, zamieszczane między listopadem 2015 a grudniem 2018 roku.

Pierwsze zdjęcie, mające związek z koncernem z branży elektronicznej, ukazało się na profilu Lewandowskiego 17 grudnia 2015 roku i było związane ze zbliżającymi się wówczas świętami Bożego Narodzenia. Na zdjęciu obok siedzącego w fotelu i uśmiechniętego sportowca widnieje podpis I Take Orders For All Your Christmas Wishes (po polsku: „Przyjmuję zamówienia na wszystkie wasze życzenia świąteczne”). Ta fotografia miała na celu promowanie specjalnej aplikacji, dzięki której użytkownicy mogli podzielić się z przyjaciółmi wcześniej przesłanymi życzeniami świątecznymi. W opisie tego zdjęcia, w formie hasztagu, znalazła się także nazwa marki Huawei ${ }^{54}$.

Najczęściej pojawiającymi się postami na koncie Lewandowskiego, na których można było zobaczyć smartfony bądź logotyp tej marki, były te złożone z kilku zdjęć. W ich opisie często pojawiał się hasztag \#PerfectPortraits, a fotografie były częścią akcji promocyjnej smartfonu Huawei $P 10$.

${ }^{53}$ Post z 10 stycznia 2014 roku na profilu Roberta Lewandowskiego na Instagramie, „Instagram.com" z 10.01.2014 r., https://www.instagram.com/p/i_OoafGIgh/ (dostęp: 8.05.2019 r.). Pierwsze zdjęcie na profilu Roberta Lewandowskiego na Instagramie przedstawia Polaka oraz jego ówczesnego kolegę z zespołu, Marco Reusa, w czasie jednego z treningów Borussii Dortmund.

${ }^{54}$ Post z 17 grudnia 2015 roku na profilu Roberta Lewandowskiego na Instagramie, promujący markę Huawei, „Instagram.com” z 17.12.2015 r., https://www.instagram.com/p/_ aAqesGIh8/ (dostęp: 7.05.2019 r.). 
Używanie $\mathrm{w}$ postach takiego hasztagu nawiązuje do ostatniego z czterech wymiarów zjawiska wizerunku, jaki wyszczególnili w swojej książce Tomasz Gackowski i Marcin Łączyński, a więc wymiaru komunikacyjnego. Według autorów ten wymiar „akcentuje głównie kanały komunikacyjne, jakimi rozchodzi się informacja kształtująca obraz firmy w umysłach odbiorców, kody używane podczas tej komunikacji (język, obrazy, symbole, stałe schematy opisu), a także role komunikacyjne w procesie tworzenia wizerunku (nadawca - pośrednik - odbiorca)"55. Przytoczone wcześniej hasztagi \#PerfectPortraits można traktować jako stałe schematy opisu, towarzyszące postom, w których Lewandowski promował model smartfonu Huawei P10. Stosowanie tego hasztagu sprawia, że w umysłach odbiorców nie tylko rozchodzi się informacja kształtująca obraz marki Huawei, ale jednocześnie w ich świadomości kształtuje się wizerunek samego piłkarza.

Między dniem 17 grudnia 2015 a 31 grudnia 2018 roku, na koncie piłkarza reprezentacji Polski opublikowano łącznie dwadzieścia dwa zdjęcia powiązane z marką Huawei oraz trzy filmiki. Związki między treścią postów, czyli tym co one przedstawiały i z czego składał się ich opis, polegały na ukazaniu w obiektywie smartfonów Huawei albo na oznaczeniu instagramowego profilu tej marki. Bardzo często zdjęcia Lewandowskiego były fotografiami typu selfie. Materiały filmowe, które pojawiały się na jego profilu, były z kolei spotami reklamowymi danego modelu smartfonu marki Huawei.

Przytaczany już post z 17 grudnia 2015 roku jest świetnym przykładem tzw. komunikowania quasi-bezpośredniego. Pojęcie to zostało przytoczone w książce „Autor jako marka. Literatura w kulturze audiowizualnej społeczeństwa informacyjnego" Dominika Antonika. Analizując twórczość Jacka Dehnela i Michała Witkowskiego, wspominał on, że taka komunikacja „poszerza wspólną przestrzeń do wymiarów wcześniej niespotykanych, gdzie niemożliwy jest fizyczny, bezpośredni kontakt, a mimo to dochodzi do nawiązania rzeczywistej interakcji i dialogu"56.

Opublikowanie postu reklamującego markę Huawei, mówiącego o możliwości przesyłania przez obserwujących Lewandowskiego na Instagramie życzeń świątecznych dzięki aplikacji, umożliwia komunikację quasi-bezpośrednią.

55 T. Gackowski, M. Łączyński (red.), dz. cyt., s. 82.

${ }^{56}$ D. Antonik, Autor jako marka. Literatura w kulturze audiowizualnej społeczeństwa informacyjnego, Kraków 2014, s. 140. Myśl ta została zaczerpnięta przez R. W. Kluszczyńskiego i została przez niego opisana. Zob. R. W. Kluszczyński, Społeczeństwo informacyjne. Cyberkultura. Sztuka multimediów, Kraków 2002, s. 19. 
Przebiega ona za pomocą mediów społecznościowych, ale mimo to możliwa jest bezpośrednia interakcja między polskim piłkarzem a internautami obserwującymi jego profil.

\section{Opublikowanie postu reklamującego markę Huawei, mówiącego o możliwości przesyłania przez obserwujących Lewandowskiego na Instagramie życzeń świątecznych dzięki aplikacji, umożliwia komunikację quasi- bezpośrednią. Przebiega ona za pomocą mediów społecznościowych, ale mimo to możliwa jest bezpośrednia interakcja między polskim piłkarzem a internautami obserwującymi jego profil.}

W jednym ze swoich artykułów Agnieszka Całek zauważyła, że zawodnik Bayernu Monachium wykorzystuje swój profil na Instagramie m.in. jako swoisty „nośnik reklamy dla marek, z którymi współpracuje”57. Na podstawie tego można stwierdzić, że Lewandowski pełni tu rolę pewnego pośrednika, mającego na celu zachęcić odbiorcę i potencjalnego klienta, aby skorzystał z oferty reklamowanej marki lub kupił jakiś produkt.

Jak widać, Instagram jest bardzo przydatnym narzędziem w reklamowaniu marek przez polskiego piłkarza. Dzięki niemu możliwe jest nawiązanie relacji z użytkownikami mediów społecznościowych, mogące zachęcić odbiorcę do tego, aby skorzystał z oferty danej marki, reklamowanej przez Lewandowskiego.

${ }^{57}$ A. Całek, Analiza obrazu: studium przypadku Anny i Roberta Lewandowskich - pierwszej pary Instagrama, w: A. Hess, M. Lisowska-Magdziarz, A. Szymańska (red.), Metody badań medioznawczych i ich zastosowanie, Kraków 2018, s. 372. 


\section{ZAKOŃCZENIE}

Analizy przytoczonych w tym artykule reklam i kampanii promocyjno-reklamowych z udziałem Roberta Lewandowskiego oraz analiza sposobu, w jaki promował produkty wybranych marek w swoich mediach społecznościowych, dowiodły, że jego wizerunek zewnętrzny w wielu przypadkach odpowiadał umiejętnościom czy wartościom, jakie reklamował. Bardzo często występował w tych reklamach jako sportowiec, co z racji na wykonywany przez niego zawód piłkarza, może być istotne w kształtowaniu obrazu swojej osoby w umysłach odbiorców.

Reklama dla marki Coca-Cola, w której Lewandowski wystąpił w 2017 roku, a także sytuacja z rozgrywanych cztery lata później mistrzostw Europy z udziałem Cristiano Ronaldo, pokazały też, że ważną rolę w procesie skutecznego budowania wizerunku może odegrać umiejętny wybór marki, z którą dana osoba współpracuje.

\section{BIBLIOGRAFIA}

[b.a.], Coca-Cola spotem z Bońkiem i Lewandowskim reklamuje się jako sponsor piłki nożnej, http://tv.wirtualnemedia.pl/film/coca-cola-spotem-z-bonkiem-i-lewandowskimreklamuje-sie-jako-sponsor-pilki-noznej (dostęp: 24.04.2019 r.).

„Vistula. Mój wybór, mój styl” - Robert Lewandowski., https://www.facebook.com/vistulathemensworld/videos/1074055715951267/ (dostęp: 9.06.2019 r.).

Antonik D., Autor jako marka. Literatura w kulturze audiowizualnej społeczeństwa informacyjnego, Kraków 2014.

Bajka Z., Krótka historia reklamy na świecie i w Polsce, „Zeszyty Prasoznawcze” 1993 nr 3-4, s. 16-47.

bg, „Pokolenie Lewandowskiego” w piłkarskiej kampanii Nike (wideo), https://www.wirtualnemedia.pl/artykul/pokolenie-lewandowskiego-w-pilkarskiej-kampanii-nikewideo (dostęp: 20.04.2019 r.).

bg, Robert Lewandowski bohaterem kampanii reklamowej Vistuli, https://www.wirtualnemedia.pl/artykul/robert-lewandowski-bohaterem-kampanii-reklamowej-vistuli (dostęp: 23.04.2019 r.).

bg, Rysunkowy Robert Lewandowski w reklamie butów Nike (wideo), https://www.wirtualnemedia.pl/artykul/rysunkowy-robert-lewandowski-w-reklamie-butow-nikewideo (dostęp: 22.04.2019 r.).

Całek A., Analiza obrazu: studium przypadku Anny i Roberta Lewandowskich - pierwszej pary Instagrama, w: A. Hess, M. Lisowska-Magdziarz, A. Szymańska (red.), Metody badań medioznawczych i ich zastosowanie, Kraków 2018, s. 361-378.

Daszkiewicz M., Wrona S., Kreowanie marki korporacyjnej, Warszawa 2014. 
Davis A., Public relations, Warszawa 2007.

Dąbrowska-Cydzik J., Cristiano Ronaldo wzgardził Coca-Colq na konferencji prasowej. "Niezgoda na promowanie niezdrowego stylu życia", https://www.wirtualnemedia.pl/ artykul/cristiano-ronaldo-bojkot-coca-cola-wybiera-woda-kryzys-wizerunkowy (dostęp: 3.11.2021 r.)

Gackowski T., Łączyński M. (red.), Metody badania wizerunku w mediach, Warszawa 2009.

Goczał B., Robert Lewandowski w reklamie Coca-Coli Zero Cukru: słuszny wybór czy marketingowa rysa na wizerunku sportowca? (opinie), „Wirtualnemedia.pl” z 8.08.2017 r., https://www.wirtualnemedia.pl/artykul/robert-lewandowski-w-reklamie-cocacoli-zero-sluszny-wybor-marketera-czy-marketingowa-rysa-na-wizerunkusportowca-opinie (dostęp: 6.11.2021 r.).

Goczał B., Robert Lewandowski zakończył współpracę z marka Coca-Cola, https://www. wirtualnemedia.pl/artykul/robert-lewandowski-zrezygnuje-z-reklam-marki-cocacola-koniec-umowy (dostęp: 24.04.2019 r.).

Gwizdek J. P., Cristiano Ronaldo surowy wobec syna. "Kiedy pije colę, jestem na niego zły", https://sport.tvp.pl/51550577/cristiano-ronaldo-jestem-zly-na-syna-kiedy-pijecoca-cole (dostęp: $3.11 .2021 \mathrm{r}$ )

jd, Robert Lewandowski twarzq kampanii Coca-Cola Zero Cukru, https://www.wirtualnemedia.pl/artykul/robert-lewandowski-reklama-coca-cola-zero-cukru-wideo (dostęp: 24.04.2019 r.).

jd, Vistula przygotowała formalne stroje dla piłkarskiej reprezentacji Polski na Mundial, https://www.wirtualnemedia.pl/artykul/pilkarska-reprezentacja-polski-strojemundial-rosja-2018 (dostęp: 24.04.2019 r.).

Kmita M., FIFA The Best. Robert Lewandowski Piłkarzem Roku na świecie! Historyczny sukces Polaka, https://sportowefakty.wp.pl/pilka-nozna/915173/fifa-the-best-robert-lewandowski-pilkarzem-roku-na-swiecie-historyczny-sukces-po (dostęp: 4.11 .2021 r.).

Kotler P., Armstrong G., Saunders J., Wong V., Marketing. Podręcznik europejski, tłum. L. Adamus, W. Kisiel, M. Woźniczka, Warszawa 2002.

KowS, Ronaldo zaszokował swoich zachowaniem na konferencji. I wypowiedział dwa słowa, https://www.sport.pl/euro/7,154862,27203465,ronaldo-podpadl-sponsorowi-euro-2020-uefa-nie-bedzie-zadowolona.html (dostęp: 30.10.2021r.)

Lisowska-Magdziarz M., Analiza zawartości mediów: przewodnik dla studentów: wersja 1.1, Kraków 2004.

Make it Possible. See my story, search for inspiration to begin your own!, https://www.facebook.com/watch/?v=1041310035914384 (dostęp: 15.04.2021 r.).

Nike Hypervenom: Robert Lewandowski. Sense the chance, strike before they realise., https://www.youtube.com/watch?v=vUoa0f5i0xo\&t=6s (dostęp: 23.04 .2019 r.). Na dzień 15.04.2021 roku, po otworzeniu tego linku, film widnieje w serwisie YouTube jako „film prywatny”. Brakuje też informacji o dacie opublikowania tego filmu (dostęp: $15.04 .2021 \mathrm{r}$.).

Oficjalny profil Roberta Lewandowskiego na Facebooku, https://www.facebook.com/ rl9official (dostęp: 7.11.2021 r.). 
Oficjalny profil Roberta Lewandowskiego na Instagramie, https://www.instagram.com/_ rl9/ (dostęp: 7.11.2021 r.).

Portal gpr24.pl, Mój wybór, mój styl - Robert Lewandowski dla Vistuli, https://gpr24.pl/ artykul/moj-wybor-moj-styl-robert-lewandowski-dla-vistuli/354363 (dostęp: 23.04.2019 r.).

Post z 10 stycznia 2014 roku na profilu Roberta Lewandowskiego na Instagramie, https://www.instagram.com/p/i_OoafGIgh/ (dostęp: 8.05.2019 r.).

Post z 16 grudnia 2018 roku na profilu Roberta Lewandowskiego na Facebooku, promujący markę Vistula, https://www.facebook.com/rl9official/photos/a.52607081 4104978/2183900558321987/?type=3\&theater (dostęp: 14.05.2019 r.).

Post z 17 grudnia 2015 roku na profilu Roberta Lewandowskiego na Instagramie, promujący markę Huawei, https://www.instagram.com/p/_aAqesGIh8/ (dostęp: 7.05. 2019 r.).

Post z 20 marca 2016 roku na profilu Roberta Lewandowskiego na Facebooku, promujący markę Vistula, https://www.facebook.com/159093717469358/photos/a.295 391460506249/1108915442487176 (dostęp: 14.04.2021 r.).

Post z 9 listopada 2015 roku na profilu Roberta Lewandowskiego na Facebooku, promujący markę Huawei, https://www.facebook.com/rl9official/photos/a.29539146050 6249/1031632156882172/?type=3\&theater (dostęp: 10.05.2019 r.).

PZPN, PZPN podpisał umowę z firmq Vistula Group SA, https://www.pzpn.pl/federacja/ aktualnosci/2016-03-10/pzpn-podpisal-umowe-z-firma-vistula-group-sa (dostęp: 10.12.2021 r.).

Robert Lewandowski Collection JZ18/19, https://www.facebook.com/vistulathemensworld/videos/287294935448406/ (dostęp: 7.06.2019 r.). Na dzień 15.04.2021 po kliknięciu w ten link filmik pojawia się na Facebooku pod adresem: https://www. facebook.com/watch/?v=287294935448406; (dostęp: 15.04.2021 r.).

Robert Lewandowski Collection JZ18/19, https://www.youtube.com/watch?v=Ksr33MrRtHs (dostęp: 20.04.2019 r.).

Sampson E., Jak tworzyć własny wizerunek, Warszawa 1996.

Sznajder A., Marketing sportu, Warszawa 2015.

tw, Coca-Cola spotem z Bońkiem i Lewandowskim reklamuje się jako sponsor piłki nożnej (wideo), https://www.wirtualnemedia.pl/artykul/coca-cola-spotem-z-bonkiemi-lewandowskim-reklamuje-sie-jako-sponsor-pilki-noznej-wideo (dostęp: 23.04 . 2019 r.).

tw, Droga Roberta Lewandowskiego do sukcesu w spocie Huawei (wideo), https://www. wirtualnemedia.pl/artykul/droga-roberta-lewandowskiego-do-sukcesu-w-spociehuawei-wideo (dostęp: 18.04.2019 r.).

tw, Robert Lewandowski międzynarodowym ambasadorem reklamowym Huawei, https:// www.wirtualnemedia.pl/artykul/robert-lewandowski-miedzynarodowymambasadorem-reklamowym-huawei (dostęp: 21.04.2019 r.).

tw, Robert Lewandowski promuje jesienno-zimowq kolekcję Vistuli (wideo), https:// www.wirtualnemedia.pl/artykul/vistula-kolekcja-robert-lewandowski-jesien-zima-2018-2019 (dostęp: 22.04.2019 r.). 
tw, Robert Lewandowski twarza Coca-Coli (wideo), https://www.wirtualnemedia.pl/arty$\mathrm{kul} /$ robert-lewandowski-twarza-coca-coli-wideo (dostęp: 23.04.2019 r.).

tw, Robert Lewandowski w samochodzie reklamuje Huawei Mate20 Pro (wideo), https:// www.wirtualnemedia.pl/artykul/huawei-mate20-pro-smartfony-reklama-robertlewandowski-w-samochodzie-wideo (dostęp: 23.04.2019 r.).

Vistula. Mój wybór, mój styl. - Robert Lewandowski, https://www.youtube.com/watch?v=EAnQKgSohoA (dostęp: 23.04.2019 r.).

Wojcik K., Public relations: od A do Z. Tom I, Warszawa 2001

Wojtas T., „To jest mój czas” - Nike rusza z kampaniq̨ na Euro 2012 (wideo), https://www. wirtualnemedia.pl/artykul/to-jest-moj-czas-nike-rusza-z-kampania-na-euro-2012wideo (dostęp: 23.04.2019 r.).

\section{Biogram}

Wojciech Skucha - magister, doktorant I roku Szkoły Doktorskiej Nauk Społecznych UJ w dyscyplinie: nauki o komunikacji społecznej i mediach. Absolwent studiów I oraz II stopnia na kierunku dziennikarstwo i komunikacja społeczna w Instytucie Dziennikarstwa, Mediów i Komunikacji Społecznej Uniwersytetu Jagiellońskiego. Zainteresowania naukowe związane są z dziennikarstwem sportowym czy mediami sportowymi.

ORCID: 0000-0002-1720-9180 